\title{
DNA barcoding and evolutionary relationships of the Phasianidae family in China
}

\author{
Z.H. Huang and D.H. Ke \\ School of Life Sciences, Jinggangshan University, \\ Ji'an, Jiangxi Province, China \\ Corresponding author: Z.H. Huang \\ E-mail: hzhow@163.com \\ Genet. Mol. Res. 13 (3): 7411-7419 (2014) \\ Received June 26, 2013 \\ Accepted March 13, 2014 \\ Published September 12, 2014 \\ DOI http://dx.doi.org/10.4238/2014.September.12.7
}

\begin{abstract}
A DNA barcode is a short sequence of standardized genomic region that is specific to a species. According to studies of bird species, the 694-bp sequence of the mitochondrial gene encoding cytochrome c oxidase 1 (COI) is extremely useful for species identification and phylogeny. In the present study, we analyzed the COI barcodes of 31 species from 18 genera belonging to the Phasianidae family in China. Kimura two-parameter (K2P) distances were calculated between barcodes. We found that the average genetic distance between congeneric species was 24 times higher compared to the average genetic distance within species. Each bird species had a barcode that was distinct to all other bird species. The neighbor-joining method was used to construct a phylogenetic tree, which grouped all of the genera into 2 divergent clades. In conclusion, DNA barcoding is an effective molecular tool for Phasianidae species identification and phylogenetic inference.
\end{abstract}

Key words: DNA barcoding; Cytochrome c oxidase I; Phasianidae; Phylogeny 


\section{INTRODUCTION}

DNA barcoding using mitochondrial cytochrome c oxidase subunit I (COI) is regarded as a standard method for species identification (Hebert et al., 2003; Arif et al., 2011). Large-scale standardized sequencing of COI has made DNA barcoding an efficient species identification tool for many animal groups (Hebert et al., 2003). Previous barcoding studies of birds have mainly focused on the survey of regional groups, in areas such as Korea (Yoo et al., 2006; Park et al., 2011), North America (Kerr et al., 2007), Southeast Asia (Lohman et al., 2009), the Neotropics (Vilaca et al., 2006; Kerr et al., 2009), and Scandinavia (Johnsen et al., 2010). However, DNA barcoding studies on specific taxa, such as Galliformes birds, remain limited.

Mitochondrial DNA (mtDNA) has been widely employed in phylogenetic studies of animals, because it evolves much more rapidly compared to nuclear DNA, resulting in the accumulation of differences among closely related species (Brown et al., 1979; Moore, 1995). Previous studies have successfully used the COI gene to discriminate bird species (Kerr et al., 2009; Johnsen et al., 2010; Ong et al., 2011; Arif et al., 2011; Breman et al., 2013). Recent reports have also extended the application of COI gene analysis into phylogenetic research (Arif et al., 2011; Breman et al., 2013).

The avian family Phasianidae is one of the most important groups of birds for both human society and research purposes. China boasts 56 species of Phasianidae belonging to 21 genera, with many of the species being distributed in the southwestern mountains and southeastern Himalayas of China (Lei and $\mathrm{Lu}, 2006$ ). There have been numerous attempts to reconstruct the phylogenetic relationships of the Phasianidae (Kimball et al., 1999, 2001; Armstrong et al., 2001; Dimcheff et al., 2002; Bush and Strobeck, 2003; Dyke et al., 2003; Pereira and Baker, 2006; Kaiser et al., 2007; Kriegs et al., 2007; Kimball and Braun, 2008; Huang et al., 2009; Liu et al., 2012). However, the taxonomic status of some species and genera within the Phasianidae family remain controversial. Different markers are required to resolve the taxonomic status of these species. However, research remains limited on the DNA barcoding of Phasianidae (Cai et al., 2010).

In the present paper, we examined the 694-bp of the COI gene of Phasianidae birds in China. A 694-bp region of the COI gene is now, by convention, used as the standard genetic marker to assist with identifying animal species (Breman et al., 2013). This study aimed to 1) test whether DNA barcodes allow the identification of Phasianidae species, 2) resolve the molecular phylogenetic relationships of Phasianidae, and to compare the results with other genetic markers.

\section{MATERIAL AND METHODS}

\section{Taxon sampling}

Sixty-eight COI sequences were obtained from the GenBank. A total of 31 species from 18 genera belonging to the Phasianidae family were analyzed (Table 1).

\section{Sequence analysis}

Sequences were aligned by the CLUSTAL X procedure (Thompson et al., 1997). A total of $694 \mathrm{bp}$ of the mtDNA COI genes were analyzed, which corresponded to the Coturnix chinensis mitochondrial genome gene start point at position 6601 and stop point at position 7294 (Nishibori et al., 2002). DnaSP v5.0 (Librado and Rozas, 2009) was used to define the variable sites. Nucleotide composition was calculated using MEGA5.0 (Tamura et al., 2011). 


\section{Table 1. Species examined in the present study and the data sources of sequences.}

\begin{tabular}{|c|c|c|c|c|c|}
\hline Genus & Species & Code & Sample size & Accession No. & Source \\
\hline \multirow[t]{4}{*}{ Tetraophasis } & Tetraophasis obscurus & Tob & 1 & NC018034 & Cai et al., 2010 \\
\hline & \multirow[t]{3}{*}{ Tetraophasis szechenyii } & \multirow[t]{3}{*}{ Tsz } & \multirow[t]{3}{*}{3} & GQ922645 & Cai et al., 2010 \\
\hline & & & & GQ922646 & Cai et al., 2010 \\
\hline & & & & GQ922647 & Cai et al., 2010 \\
\hline Tetraogallus & Tetraogallus altaicus & Tal & 1 & GQ482760 & Kerr et al., 2009 \\
\hline \multirow[t]{3}{*}{ Alectoris } & \multirow[t]{3}{*}{ Alectoris chukar } & \multirow[t]{3}{*}{ Ach } & \multirow[t]{3}{*}{3} & FJ752426 & Shen et al., 2010 \\
\hline & & & & JF498827 & Kerr and Dove, unpublished data \\
\hline & & & & JF498828 & Kerr and Dove, unpublished data \\
\hline \multirow[t]{2}{*}{ Francolinus } & \multirow[t]{2}{*}{ Francolinus pintadeanus } & \multirow[t]{2}{*}{ Fpi } & \multirow[t]{2}{*}{2} & NC011817 & Shen et al., 2009 \\
\hline & & & & EU165707 & Shen et al., 2009 \\
\hline \multirow[t]{6}{*}{ Perdix } & Perdix dauurica & Pda & 3 & FJ752431 & Shen et al., 2010 \\
\hline & & & & GQ482330 & Kerr et al., 2010 \\
\hline & & & & GQ482331 & Kerr et al., 2010 \\
\hline & Perdix perdix & Ppe & 3 & GU571528 & Johnsen et al., unpublished data \\
\hline & & & & GU571529 & Johnsen et al., unpublished data \\
\hline & & & & DQ433893 & Kerr et al., 2007 \\
\hline Coturnix & Coturnix chinensis & Cch & 1 & AB073301 & Nishibori et al., 2002 \\
\hline & Coturnix japonica & $\mathrm{Cja}$ & 3 & GQ481651 & Kerr et al., 2009 \\
\hline & & & & GQ481653 & Kerr et al., 2009 \\
\hline & & & & AP003195 & Nishibori et al., 2002 \\
\hline & Coturnix coturnix & Cco & 2 & GQ481648 & Kerr et al., 2009 \\
\hline & & & & GQ481649 & Kerr et al., 2009 \\
\hline Arborophila & Arborophila rufogularis & Aru & 2 & GQ922643 & Cai et al., 2010 \\
\hline & & & & GQ922644 & Cai et al., 2010 \\
\hline & Arborophila gingica & Agi & 1 & FJ752425 & Shen et al., 2010 \\
\hline Bambusicola & Bambusicola thoracica & Bth & 2 & EU165706 & Shen et al., 2009 \\
\hline & & & & NC011816 & Shen et al., 2009 \\
\hline & Bambusicola fytchii & Bfy & 1 & FJ752423 & Shen et al., 2010 \\
\hline Ithaginis & Ithaginis cruentus & Icr & 1 & GQ922649 & Cai et al., 2010 \\
\hline Tragopan & Tragopan caboti & Tca & 2 & NC013619 & Kan et al., 2010 \\
\hline & & & & GU187969 & Kan et al., 2010 \\
\hline & Tragopan temminckii & Tte & 3 & FJ752427 & Shen et al., 2010 \\
\hline & & & & GQ922634 & Cai et al., 2010 \\
\hline & & & & GQ922635 & Cai et al., 2010 \\
\hline Pucrasia & Pucrasia macrolopha & Pma & 2 & FJ752429 & Shen et al., 2010 \\
\hline & & & & GQ922648 & Cai et al., 2010 \\
\hline Lophophorus & Lophophorus lhuysii & Llh & 2 & NC013979 & Ma et al., 2010 \\
\hline & & & & GQ871234 & Ma et al., 2010 \\
\hline Gallus & Gallus gallus & Gga & 2 & AY235570 & Froman and Kirby, 2005 \\
\hline & & & & GQ922621 & Cai et al., 2010 \\
\hline Lophura & Lophura nycthemera & Lny & 3 & EU417810 & Shen et al., 2009 \\
\hline & & & & NC012895 & Shen et al., 2009 \\
\hline & & & & GQ922620 & Cai et al., 2010 \\
\hline & Lophura ignita & Lig & 2 & NC010781 & Kato et al., unpublished data \\
\hline & & & & AB164627 & Kato et al., unpublished data \\
\hline Crossoptilon & Crossoptilon auritum & $\mathrm{Cau}$ & 3 & GQ922639 & Cai et al., 2010 \\
\hline & & & & GQ922640 & Cai et al., 2010 \\
\hline & & & & NC015897 & $\mathrm{Li}$ and $\mathrm{Kan}$, unpublished data \\
\hline & Crossoptilon crossoptilon & Ccr & 3 & GQ922613 & Cai et al., 2010 \\
\hline & & & & GQ922614 & Cai et al., 2010 \\
\hline & & & & NC016679 & Zhao and Zou, unpublished data \\
\hline Syrmaticus & Syrmaticus reevesii & Sre & 2 & AB164623 & Kato et al., unpublished data \\
\hline & & & & NC010770 & Kato et al., unpublished data \\
\hline & Syrmaticus humiae & Shu & 2 & NC010774 & Kato et al., unpublished data \\
\hline & & & & AB164625 & Kato et al., unpublished data \\
\hline & Syrmaticus soemmerringi & Sso & 2 & $\mathrm{AB} 164622$ & Kato et al., unpublished data \\
\hline & & & & NC010767 & Kato et al., unpublished data \\
\hline Phasianus & Phasianus colchicus & Pco & 3 & GQ482363 & Kerr et al., 2009 \\
\hline & & & & NC015526 & Kan and $\mathrm{Li}$, unpublished data \\
\hline & & & & JF739859 & Kan and $\mathrm{Li}$, unpublished data \\
\hline Chrysolophus & Chrysolophus pictus & Cpi & 3 & NC014576 & Qin and Shi, unpublished data \\
\hline & & & & FJ752433 & Shen et al., 2010 \\
\hline & & & & HQ221859 & Qin and Shi, unpublished data \\
\hline & Chrysolophus amherstiae & Cam & 3 & FJ752434 & Shen et al., 2010 \\
\hline & & & & GQ922606 & Cai et al., 2010 \\
\hline & & & & GQ922608 & Cai et al., 2010 \\
\hline
\end{tabular}


Sequence divergence among species and genera was calculated using the Kimura two-parameter (K2P, Kimura, 1980) distance model in MEGA 5.0 (Table 1). All positions containing gaps were deleted from the dataset using the "complete deletion" option, and the vertebrate mitochondrial code was used throughout. Neighbor-joining (NJ) (Saitou and Nei, 1987) trees of K2P distances were created to provide a graphic representation of the pattern of divergence among species. Node support was assessed using the bootstrap method (Felsenstein, 1985).

\section{RESULTS}

\section{Barcoding analysis}

Of the 66 sequences from the 31 species, 2 individuals were analyzed per species, on average. None of the sequences had a DNA barcoding gap. All of the bird species had distinct COI sequences, of which none was shared between species. The average nucleotide composition was $28.0 \% \mathrm{~T}, 31.2 \% \mathrm{C}, 24.8 \% \mathrm{~A}$, and $16.0 \% \mathrm{G}$. The sum content of $\mathrm{A}$ and $\mathrm{T}$ exceeded $50 \%$. Two hundred and forty-nine variable sites were identified, of which 237 were parsimoniously informative (i.e., $34.15 \%$ of the entire sequence).

Intraspecific genetic distances ranged from 0.0 to $1.6 \%$. COI sequence divergences among congeneric species ranged from $1.6 \%$ (Coturnix japonica and Coturnix coturnix) to $14.2 \%$ (Coturnix chinensis and Coturnix coturnix) when all of the species examined were included in the analysis. The average difference in the COI sequence between species from each genus (7.2\%) was 24 times higher compared to the average difference within a given species $(0.3 \%)$. The genetic distance among the 18 genera ranged from $9.0 \%$ (Lophura and Crossoptilon, Lophura, and Chrysolophus) to 20.2\% (Perdix and Arborophila) (Table 2).

Table 2. Genetic distance among the 18 genera belonging to the Phasianidae family.

\begin{tabular}{|c|c|c|c|c|c|c|c|c|c|c|c|c|c|c|c|c|c|}
\hline & $1^{*}$ & 2 & 3 & 4 & 5 & 6 & 7 & 8 & 9 & 10 & 11 & 12 & 13 & 14 & 15 & 16 & 17 \\
\hline & 0.137 & & & & & & & & & & & & & & & & \\
\hline 3 & 0.150 & 0.124 & & & & & & & & & & & & & & & \\
\hline 4 & 0.142 & 0.138 & 0.126 & & & & & & & & & & & & & & \\
\hline 5 & 0.178 & 0.180 & 0.163 & 0.165 & & & & & & & & & & & & & \\
\hline 6 & 0.141 & 0.147 & 0.16 & 0.150 & 0.171 & & & & & & & & & & & & \\
\hline 7 & 0.163 & 0.16 & 0.165 & 0.181 & 0.202 & 0.174 & & & & & & & & & & & \\
\hline 8 & 0.144 & 0.148 & 0.133 & 0.128 & 0.171 & 0.16 & 0.164 & & & & & & & & & & \\
\hline 9 & 0.131 & 0.152 & 0.153 & 0.145 & 0.161 & 0.151 & 0.173 & 0.141 & & & & & & & & & \\
\hline 10 & 0.144 & 0.159 & 0.163 & 0.168 & 0.169 & 0.181 & 0.186 & 0.174 & 0.169 & & & & & & & & \\
\hline 11 & 0.119 & 0.146 & 0.158 & 0.123 & 0.151 & 0.147 & 0.173 & 0.143 & 0.141 & 0.159 & & & & & & & \\
\hline 12 & 0.110 & 0.149 & 0.152 & 0.127 & 0.171 & 0.160 & 0.175 & 0.136 & 0.129 & 0.132 & 0.127 & & & & & & \\
\hline 13 & 0.139 & 0.151 & 0.134 & 0.111 & 0.164 & 0.156 & 0.160 & 0.133 & 0.159 & 0.152 & 0.139 & 0.153 & & & & & \\
\hline 14 & 0.132 & 0.161 & 0.166 & 0.131 & 0.160 & 0.165 & 0.192 & 0.159 & 0.158 & 0.166 & 0.121 & 0.149 & 0.144 & & & & \\
\hline 15 & 0.146 & 0.171 & 0.172 & 0.149 & 0.169 & 0.168 & 0.189 & 0.180 & 0.158 & 0.166 & 0.130 & 0.166 & 0.152 & 0.090 & & & \\
\hline 16 & 0.134 & 0.150 & 0.142 & 0.152 & 0.156 & 0.156 & 0.178 & 0.156 & 0.158 & 0.158 & 0.125 & 0.139 & 0.146 & 0.117 & 0.117 & & \\
\hline 17 & 0.154 & 0.170 & 0.175 & 0.171 & 0.168 & 0.173 & 0.199 & 0.168 & 0.181 & 0.179 & 0.147 & 0.161 & 0.139 & 0.110 & 0.132 & 0.129 & \\
\hline 18 & 0.144 & 0.181 & 0.161 & 0.157 & 0.146 & 0.172 & 0.186 & 0.174 & 0.171 & 0.181 & 0.126 & 0.163 & 0.159 & 0.090 & 0.109 & 0.127 & 0.110 \\
\hline
\end{tabular}

\section{Phylogenetic relationships}

The species could be discriminated by their distinct clusters in the phylogenetic tree (Fig- 
ure 1). The phylogenetic tree showed low intraspecific and large interspecific divergences with strong bootstrap support (Figure 1). All the 18 genera were grouped into 2 clearly divergent clades (A and B, Figure 1). The genetic distance between A and B was 16.3\% based on K2P model.

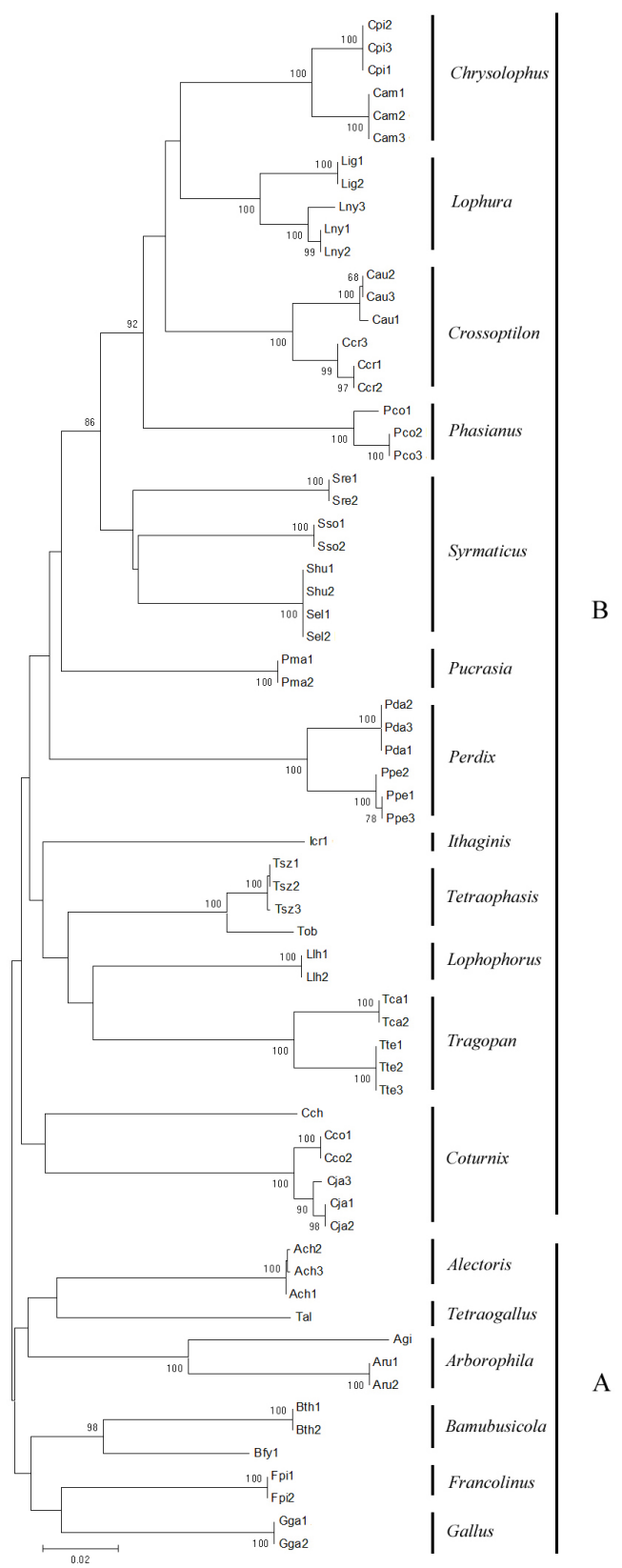

Figure1. Phylogenetic trees of eighteen genera of phasianidae constructed from mtDNA COI sequence. Numbers (in internodes) represent bootstrap values $(\geq 80 \%)$ from 10,000 replications. The codes were shown in Table 1. 
Clade A contained 6 genera (Alectoris, Tetraogallus, Arborophila, Bambusicola, Francolinus, and Gallus). Analysis of COI genes supported the inclusion of Alectoris, Tetraogallus, and Arborophila in a subclade. Bambusicola, Francolinus, and Gallus formed the other subclade (Figure 1).

Clade B contained the other 12 genera, which were separated into 3 subclades. Members of Coturnix formed one subclade. NJ analysis grouped Ithaginis, Tetraophasis, Lophophorus, and Tragopan into another subclade. The third subclade contained the other 7 genera (Figure 1).

\section{DISCUSSION}

Many preceding studies of birds have already ascertained the reliability of COI barcodes. These studies have confirmed a clear gap (the so-called barcoding gap) between intraand interspecific K2P distance distributions (Breman et al., 2013). Hebert et al. (2004) suggested a "10x rule," which is a sequence threshold of 10 times the mean intraspecific variation for the group under study, to screen for splits referred to as putative species. However, Park et al. (2011) found that the CO1 sequence difference between closely related species $(5.0 \%)$ was 25 times higher compared to within species differences $(0.2 \%)$. This result was similar to the value obtained in the present study and by Yoo et al. (2006). In comparison, Scandinavian birds produced much higher differences, of up to 33 times (Johnsen et al., 2010). The rate of COI gene evolution is subject to variation in different clades of birds (Pereira and Baker, 2006). Therefore, it might be inappropriate to suggest a universal distance criterion for different species. In any case, distance-based DNA barcoding seems to provide sufficient information to identify and delineate a large majority of bird species, including those belonging to the Phasianidae family, through pairwise comparisons (Yoo et al., 2006; Kerr et al., 2007; Tavares and Baker, 2008; Aliabadian et al., 2009; Johnsen et al., 2010; Cai et al., 2010; Breman et al., 2013). These preceding studies also indicate that the COI barcode facilitated the separation of even the most closely related species.

The results of the present study clearly demonstrated the discriminatory power of COI barcodes for the identification of Phasianidae species. Phylogenetic analysis separated the different Phasianidae species into distinct branches, with high bootstrap support. None of the species shared sequences or had overlapping clusters with another species.

Phasianidae are a well-studied group of birds; however, some aspects of their evolutionary relationships remain unclear or ambiguous. Here, we provide the first phylogenetic analysis for Phasianidae using the COI gene. The phylogenetic tree grouped all the 18 genera into 2 divergent clades (Figure 1). In clade B (Figure 1), the taxonomic status of Pucrasia, Perdix, and Coturnix remained unresolved. Members of these 3 genera are generally monochromatic, with no highly dimorphic or ornamented species, and are considered to be partridges (Cheng, 1978). This feature contrasts with species in the other genera of clade A, most of which have males with a high degree of ornamentation, and are considered to be pheasants. Kimball et al. (1999) suggested that the terms pheasant and partridge should only be used to include suites of related behavioral and morphological traits, rather than implying anything about the evolutionary history of Phasianidae birds.

COI gene analysis well supported the inclusion of Chrysolophus, Lophura, Crossoptilon, Phasianus, and Syrmaticus in a single lineage (Figure 1). These genera exhibit a high 
degree of ornamentation, with males having elongated tails and crests. Behaviorally, males are often polygynous, and do not tend to participate in parental care. Members of the 5 genera have been shown to be typical pheasants (Cheng, 1978). Molecular data were consistent with the morphology and behavior observed for these genera. Chrysolophus has been frequently grouped with Phasianus in many previously published studies (Kimball and Braun, 2008), which contradict the results presented here. This may be due to different genetic markers. Another, hybridization is widespread in Galliformes birds. Chrysolophus can hybridize with Lophura and Phasianus (McCarthy, 2006). Hybridization presents challenges to the reconstruction of phylogenies (Grant and Grant, 1992). NJ analysis grouped Tragopan with 3 other genera (Ithaginis, Tetraophasis, and Lophophorus) to form a single subclade, which was consistent with the results proposed by the mtDNA control-region gene (Huang et al., 2009).

In conclusion, DNA barcoding is an effective molecular tool for species identification and phylogenetic inference. Since this technique is based on molecular-level variation, it offers greater accuracy and authenticity compared to the more subjective plumage-based phylogeny of birds (Arif et al., 2011).

\section{ACKNOWLEDGMENTS}

Research supported by the National Natural Science Foundation of China (\#30960051, \#31260088), Jiangxi Province Talent Project 555, Jiangxi Province Major Disciplines Academic Leaders (\#2013BCB22010), the Natural Science Foundation of Jiangxi Province (\#20132BAB204022), and the Science and Technology Foundation of Jiangxi Provincial Department of Education (\#GJJ11529).

\section{REFERENCES}

Aliabadian M, Kaboli M, Nijman V and Vences M (2009). Molecular identification of birds: performance of distancebased DNA barcoding in three genes to delimit parapatric species. PLoS One 4: e4119.

Arif IA, Khan HA, Shobrak M and Williams J (2011). Cytochrome c oxidase subunit I barcoding of the green bee-eater (Merops orientalis). Genet. Mol. Res. 10: 3992-3998.

Armstrong MH, Braun EL and Kimball RT (2001). Phylogenetic utility of avian ovomucoid intron G: a comparison of nuclear and mitochondrial phylogenies in Galliformes. The Auk 118: 799-804.

Breman FC, Jordaens K, Sonet G, Nagy ZT, et al. (2013). DNA barcoding and evolutionary relationships in Accipiter Brisson, 1760 (Aves, Falconiformes: Accipitridae) with a focus on African and Eurasian representatives. J. Ornithol. 154: 265-287.

Brown WM, George M, Jr. and Wilson AC (1979). Rapid evolution of animal mitochondrial DNA. Proc. Natl. Acad. Sci. U.S. A. 76: 1967-1971.

Bush KL and Strobeck C (2003). Phylogenetic relationships of the Phasianidae reveals possible non-pheasant taxa. $J$. Hered. 94: 472-489.

Cai Y, Yue B, Jiang W, Xie S, et al. (2010). DNA barcoding on subsets of three families in Aves. Mitochondrial DNA 21: 132-137.

Cheng TH (1978). Fauna Sinica, Aves Vol. 4: Galliformes. Science Press, Beijing.

Dimcheff DE, Drovetski SV and Mindell DP (2002). Phylogeny of Tetraoninae and other galliform birds using mitochondrial 12S and ND2 genes. Mol. Phylogenet. Evol. 24: 203-215.

Dyke GJ, Gulas BE and Crowe TM (2003). Suprageneric relationships of galliform bird (Aves, Galliformes): a cladistic analysis of morphological characters. Zool. J. Linn. Soc. 137: 227-244.

Felsenstein J (1985). Confidence limits on phylogenies: an approach using the bootstrap. Evolution 39: 783-791

Froman DP and Kirby JD (2005). Sperm mobility: phenotype in roosters (Gallus domesticus) determined by mitochondrial function. Biol. Reprod. 72: 562-567. 
Grant PR and Grant BR (1992). Hybridization of bird species. Science 256: 193-197.

Hebert PD, Cywinska A, Ball SL and deWaard JR (2003). Biological identifications through DNA barcodes. Proc. Biol. Sci. 270: 313-321.

Hebert PD, Stoeckle MY, Zemlak TS and Francis CM (2004). Identification of Birds through DNA Barcodes. PLoS Biol. 2: $\mathrm{e} 312$.

Huang Z, Liu N, Xiao Y, Cheng Y, et al. (2009). Phylogenetic relationships of four endemic genera of the Phasianidae in China based on mitochondrial DNA control-region genes. Mol. Phylogenet. Evol. 53: 378-383.

Johnsen A, Rindal E, Ericson PGP, Zuccon D, et al. (2010). DNA barcoding of Scandinavian birds reveals divergent lineages in trans-Atlantic species. J. Ornithol. 151: 565-578.

Kaiser VB, van Tuinen M and Ellegren H (2007). Insertion events of cr1 retrotransposable elements elucidate the phylogenetic branching order in Galliform birds. Mol. Biol. Evol. 24: 338-347.

Kan XZ, Li XF, Lei ZP, Wang M, et al. (2010). Complete mitochondrial genome of Cabot's tragopan, Tragopan caboti (Galliformes: Phasianidae). Genet. Mol. Res. 9: 1204-1216.

Kerr KC, Stoeckle MY, Dove CJ, Weigt LA, et al. (2007). Comprehensive DNA barcode coverage of North American birds. Mol. Ecol. Notes 7: 535-543.

Kerr KC, Birks SM, Kalyakin MV, Red'kin YA, et al. (2009). Filling the gap - COI barcode resolution in eastern Palearctic birds. Front Zool. 6: 29.

Kimball RT, Braun EL, Zwartjes PW, Crowe TM, et al. (1999). A molecular phylogeny of the pheasants and partridges suggests that these lineages are not monophyletic. Mol. Phylogenet. Evol. 11: 38-54.

Kimball RT, Braun EL, Ligon JD, Lucchini V, et al. (2001). A molecular phylogeny of the peacock-pheasants (Galliformes: Polyplectron spp.) indicates loss and reduction of ornamental traits and display behaviours. Biol. J. Linn. Soc. 73: 187-198.

Kimball RT and Braun EL (2008). A multigene phylogeny of Galliformes supports a single origin of erectile ability in non-feathered facial traits. J. Avian Biol. 39: 438-445.

Kimura M (1980). A simple method for estimating evolutionary rates of base substitutions through comparative studies of nucleotide sequences. J. Mol. Evol. 16: 111-120.

Kriegs JO, Matzke A, Churakov G, Kuritzin A, et al. (2007). Waves of genomic hitchhikers shed light on the evolution of gamebirds (Aves: Galliformes). BMC Evol. Biol. 7: 190.

Lei LF and Lu TC (2006). China Endemic Birds. Science Press, Beijing.

Librado P and Rozas J (2009). DnaSP v5: a software for comprehensive analysis of DNA polymorphism data. Bioinformatics 25: 1451-1452.

Liu Z, He L, Yuan H, Yue B, et al. (2012). CR1 retroposons provide a new insight into the phylogeny of Phasianidae species (Aves: Galliformes). Gene 502: 125-132.

Lohman DJ, Prawiradilaga DM and Meier R (2009). Improved COI barcoding primers for Southeast Asian perching birds (Aves: Passeriformes). Mol. Ecol. Resour. 9: 37-40.

Ma le L, Zhang XY, Yue BS and Ran JH (2010). Complete mitochondrial genome of the Chinese Monal pheasant Lophophorus lhuysii, with phylogenetic implication in Phasianidae. Mitochondrial DNA 21: 5-7.

McCarthy EM (2006). Handbook of Avian Hybrids of the World. Oxford University Press.

Moore WS (1995). Inferring phylogenies from mtDNA variation: Mitochondrial-gene trees versus nuclear-gene trees. Evolution 49: 718-726.

Nishibori M, Tsudzuki M, Hayashi T, Yamamoto Y, et al. (2002). Complete nucleotide sequence of the Coturnix chinensis (blue-breasted quail) mitochondrial genome and a phylogenetic analysis with related species. J. Hered. 93: 439-444.

Ong PS, Luczon AU, Quilang JP, Sumaya AM, et al. (2011). DNA barcodes of Philippine accipitrids. Mol. Ecol. Resour. 11: 245-254.

Park HY, Yoo HS, Jung G and Kim CB (2011). New DNA barcodes for identification of Korean birds. Genes Genom. 33: 91-95.

Pereira SL and Baker AJ (2006). A molecular timescale for galliform birds accounting for uncertainty in time estimates and heterogeneity of rates of DNA substitutions across lineages and sites. Mol. Phylogenet. Evol. 38: 499-509.

Saitou N and Nei M (1987). The neighbor-joining method: a new method for reconstructing phylogenetic trees. Mol. Biol. Evol. 4: 406-425.

Shen YY, Shi P, Sun YB and Zhang YP (2009). Relaxation of selective constraints on avian mitochondrial DNA following the degeneration of flight ability. Genome Res. 19: 1760-1765.

Shen YY, Liang L, Sun YB, Yue BS, et al. (2010). A mitogenomic perspective on the ancient, rapid radiation in the Galliformes with an emphasis on the Phasianidae. BMC Evol. Biol. 10: 132.

Tamura K, Peterson D, Peterson N, Stecher G, et al. (2011). MEGA5: molecular evolutionary genetics analysis using maximum likelihood, evolutionary distance, and maximum parsimony methods. Mol. Biol. Evol. 28: 2731-2739.

Genetics and Molecular Research 13 (3): 7411-7419 (2014)

CFUNPEC-RP www.funpecrp.com.br 
Tavares ES and Baker AJ (2008). Single mitochondrial gene barcodes reliably identify sister-species in diverse clades of birds. BMC Evol. Biol. 8: 81.

Thompson JD, Gibson TJ, Plewniak F, Jeanmougin F, et al. (1997). The CLUSTAL_X windows interface: flexible strategies for multiple sequence alignment aided by quality analysis tools. Nucleic Acids Res. 25: 4876-4882.

Vilaça ST, Lacerda DR, Sari HER and Santos FR (2006). DNA-based identification applied to Thamnophilidae (Passeriformes) species: the first barcodes of Neotropical birds. Rev. Bras. Ornitol. 14: 7-13.

Yoo HS, Eah JY, Kim JS, Kim YJ, et al. (2006). DNA barcoding Korean birds. Mol. Cells 22: 323-327. 